\title{
Rural entrepreneurship and rural development in Nigeria
}

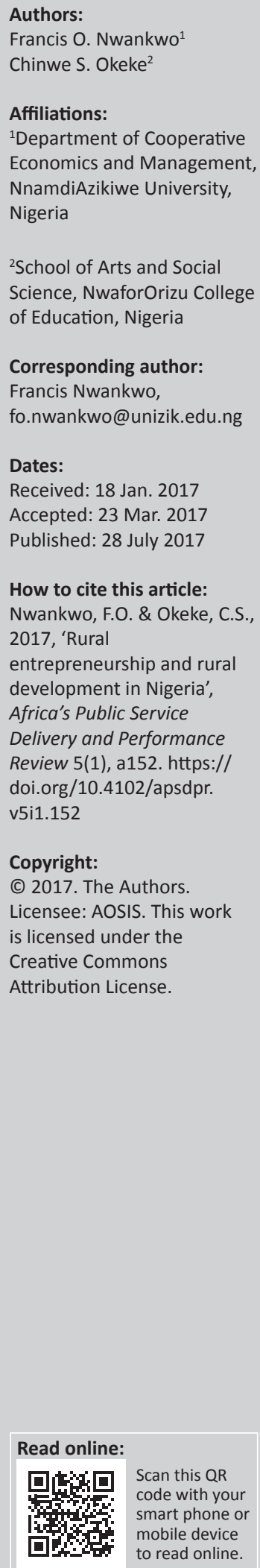

Rural entrepreneurship can help develop rural areas through good management of the local resources. Within the framework of integrated rural development theory, this study attempts to determine the perceptions of rural entrepreneurs on the nature and role of entrepreneurship in rural economic development. The study adopted the survey and descriptive design. The researchers randomly selected 200 rural entrepreneurs from five towns in Oyi Local Government Area. The major source of data was primary data, though secondary data such as journals, textbooks and Internet materials were also consulted. A 24-item questionnaire of strongly agree, agree, disagree and strongly disagree was designed and administered. Findings showed that rural entrepreneurship can help increase output, create employment and reduce rural urban migration among other things. However, rural entrepreneurs are faced with certain challenges such as insufficient funds and lack of government support. Based on these findings, the researchers recommended that rural areas should be made attractive and government should create enabling environments for rural entrepreneurs through their policies and other assistance.

\section{Introduction}

Governments in developing countries have now come to the realisation that no development will be meaningful except when the rural communities are also carried along. This realisation is borne out of the reality that rural dwellers constitute a significant component of their population. Indeed, Onibokun (1987) in his policy paper revealed that the rural population constitutes $70 \%-80 \%$ of the entire population of most third world countries. Nigeria's rural dwellers constitute $53 \%$ of the country's total population (World Bank 2015). The bulk of Nigeria's food and fibre supply come from the rural areas, whose production of cassava, palm produce, etc. has long contributed significantly to the country's gross domestic product (GDP). However, poverty and infrastructural deficits are a common phenomenon in Nigeria's rural sector. Egwemi and Odo (2013) observe that Nigeria still falls far short of the economic and social progress required to impact the well-being of the average Nigerian, given that over half of Nigeria's population live on less than 1 dollar a day. These obviously suggest the need for attention to rural areas for sustainable development. Taking cognisance of the level of economic activities in rural development, it becomes apparent that action must be taken to ensure sustainable rural development.

Rural development is a strategy designed to improve the economic and social life of the rural poor (Umembali \& Akubuilo 2006). Deji (2005) sees rural development as a way of restructuring the national economy to bring about improvement in the standard of living of people in rural areas. But rural development cannot be achieved unless certain strategies are used. Ebiriwa (2005) outlines some approaches to rural development as modernisation approach, transformation approach and demonstration approach, while Nwobi (2007) adds agricultural approach, internal combustion approach, basic resource approach, etc. to the list. Each of the listed strategies has contributed in one way or an other to the development of rural areas. However, the inclusion of rural entrepreneurship as a strategy appears to be capable of contributing much more.

\section{Statement of problem}

The poor state of most rural economies is very devastating and pathetic. Rural areas have peculiar problems of low income, low productivity, high degree of unemployment, high population rate, poor technological growth, low infrastructures, high illiteracy rate, malnutrition, etc. Entrepreneurial orientation to rural development, in contrast to development based on bringing in human capital and investment from outside, is based on stimulating local entrepreneurial talent and the subsequent growth of indigenous companies. This in turn would create jobs and 
add economic value to a region and community and at the same time keep scarce resources within the community. To accelerate economic development in rural areas, it is necessary to increase the supply of entrepreneurs, thus building up the critical mass of first-generation entrepreneurs (Petrin 1992). But there are worries that progress in the promotion of rural entrepreneurship may be hindered by lack of or inadequate understanding of its concept and role in the rural sector. Institution of appropriate promotional policies cannot be guaranteed unless there is adequate knowledge of rural entrepreneurship (on the part of the people) and its potential in rural development. Therefore, the focus of this study was to investigate the perception of rural entrepreneurs on the nature and role of entrepreneurship in rural economic development.

\section{Conceptual and theoretical review}

The earliest definition of entrepreneurship sees it as an economic term which describes the process of bearing the risk of buying at certain prices and selling at uncertain prices (Di-Masi 2000). Later commentators, however, broadened this definition to include the concept of bringing together the factors of production. But this definition according to DiMasi (2008) led others to question whether there was any unique entrepreneurial function or whether it was simply a form of management. The concept of innovation was added to the definition of entrepreneurship by theorists in the early part of this century. This innovation could be process innovation, market innovation, product innovation, factor innovation, and even organisational innovation. Later definitions described entrepreneurship as involving the creation of new enterprises and that the entrepreneur is the founder.

On the role of rural entrepreneurship in the development process, Naudes (2008) states that an effective entrepreneurship venture fosters the production of wealth for a nation, creates jobs that utilise human resources and also reduces economic waste. He maintained that the income level of the average person and the standard of living of a society increase with every successful entrepreneurship project; nonetheless, entrepreneurship originated out of trade by barter. Ejiofor (1989) points out that entrepreneurship is the first step towards a self-reliant economy that can generate internal self-sustaining economic growth and development. In the same vein, Brain (2005) states that entrepreneurs occupy a central position in a market economy, and there are never enough of them. A society is adjudged prosperous only to the degree to which it rewards and encourages entrepreneurial activity. Entrepreneurial activities are the critical determinants of the level of success, prosperity, growth and opportunity in any country.

Entrepreneurship though desirable is usually fraught with difficulties and risks. Onyekwelu, Uzor and Chiekezie (2008), citing Hisrich and Peters (2002), note that entrepreneurship is the process of creating something different with values by devoting necessary time and effort, assuming the accompanying financial, psychological and social risks and receiving resulting rewards of monetary and personal satisfaction and independence. Nzelibe (1996) and Redmond (2008) see entrepreneurs as action-oriented, highly motivated individuals who take risks to achieve goals.

Basically, entrepreneurs must possess distinctive qualities that will help them to excel. Gana (2001) reveals that every entrepreneur possesses positive and negative qualities. He therefore advises that the entrepreneur must effectively use his positive qualities like risk taking, decision making, planning, self-confidence, creativity, uniqueness, futuristic, drive and energy to overcome the negative qualities such as arrogance for business success. When entrepreneurs effectively combine these qualities they are able to perform useful functions.

Rural entrepreneurship, conceptually speaking, is not much different from entrepreneurship. Indeed, rural entrepreneurship could be seen as using the process and methods of entrepreneurship to exploit untapped potential of rural areas, to bring about growth and development. Petrin (1994) describes rural entrepreneurship as:

a force that mobilises other resources to meet unmet market demand, the ability to create and build something from practically nothing, the process of creating value by pulling together a unique package of resources to exploit an opportunity.

Onyekwelu et al. (2008) highlight some pro-development entrepreneurial functions such as identification of investment opportunities, formation and nurturing of enterprises, assembling and coordinating of resources (human and material), invention, innovation, risk bearing, decisionmaking, etc. These functions according to them are not left only for entrepreneurs in the urban areas but also for the rural entrepreneurs. Rural entrepreneurs are individuals who find investment opportunities in the rural areas.

The strategic role rural entrepreneurship could play in rural development appears to have caught the attention of policymakers and development experts. Petrin (1994) notes that institutions and individuals promoting rural development now see entrepreneurship as a strategic development intervention that could accelerate the rural development process. In his words development agencies see rural entrepreneurship as an enormous employment potential, politicians see it as the key strategy to prevent rural unrest, farmers see it as an instrument for improving farm earnings while women see it as an employment possibility near their homes which provide autonomy, independence and a reduced need for social support. Clearly, entrepreneurship is seen as a vehicle for improving the quality of life for individuals, families and communities as well as to sustain a healthy economy and environment. He stresses that to accelerate economic development in rural areas, it is necessary to increase the supply of entrepreneurs who will take risks and engage in the uncertainties of new venture creation. 
Sherief (2008) is equally emphatic about a possible role rural entrepreneurship could play in rural development. He notes in particular that entrepreneurial orientation in rural areas is based on stimulating local entrepreneurial talent and subsequent growth of indigenous companies, which in turn would create jobs and add economic value to a region, and at the same time keep scarce resources within the community. Indeed, this optimism is anchored on studies conducted by Economic Commission for Latin America and Caribbean (ECLAC) and Food and Agricultural Organisation (FAO) in the Latin American and Caribbean region which have shown that rural enterprises can be an important modernising agent for small agriculture. Thus, government have supported this process by creating incentives for agro-industry to invest in such regions.

Rural entrepreneurs are people who are prepared to stay in the rural areas and contribute to the creation of local wealth (Petrin 1994). According to Perpar (2007), rural areas are isolated, economically poor, depopulated and un-mechanised. Based on this, local entrepreneurial talents have to be harnessed, and consequently, the growth of indigenous companies should be encouraged and promoted. This will create jobs, add economic value to the region and, at the same time, retain the scarce resources within the local area.

Of all available theories that could be used to unravel our subject matter under investigation, the integrated rural development theory is perhaps the most potent. Integrated rural development theory is a multidimensional strategy for improving the quality of life of the rural people. It is based on the premise that the socioeconomic framework of the traditional rural system is obsolete; therefore, integrated rural development strategies are designed to change this framework and promote structural changes in society (Akhakpe, Fatile \& Igbokwe-Ibeto 2012). The Directorate of Food, Roads and Rural Infrastructure (DFRRI) of Babangida's administration is a typical example of this approach to rural development in Nigeria.

In spite of the clamour for the promotion of rural entrepreneurship as an effective rural development channel, there is evidence that certain socioeconomic challenges could beset it, thereby truncating the desired benefits that would be realised. A major challenge here could be linked to the remoteness of the rural business environment which, according to Sherief, is symptomised by a lack of local industrial and service milieu, meaning that there are fewer opportunities for firms to subcontract out locally than in an urban centre. Again, and from the point of view of innovation specifically, the low density of the business population results in a small number of potential collaborating firms locally, as well as more sparsely distributed research and development, educational institutions and business support providers compared with some other types of location.

In the Nigerian context, inadequate or dearth of infrastructural facilities have impacted negatively on the business environment, including rural entrepreneurship. Okeke and Eme (2014) note that poor access to infrastructure affects a large percentage of the population. Only about one in every three households in rural areas has electricity and even when it is available, the supply of electricity is often erratic. Agbola and Ukaegbu (2006) point to the devastating effect of poor infrastructural facilities - erratic power supply, poor condition of road network and inadequate water supply - on emerging businesses. Perhaps, one singular constraint that discourages entrepreneurship and business growth in the rural sector is the security challenges posed by Boko Haram insurgency in the north-east and Niger Delta militancy in the south of Nigeria.

United Nations Development Project (UNDP), cited in Sherief (2008), has summarised the problems faced by rural small- and medium-scale enterprises (SMEs) and suggested initiatives that may be undertaken to solve these issues. These are presented in Box 1 .

\section{Methodology}

The study adopts an exploratory research design. Data for the study were obtained from rural entrepreneurs in five communities of the Oyi Local Government Area (LGA). These are Umunya, Awkuzu, Nkwelle, Ogbunike and Nteje. The Oyi local government is in the northern senatorial zone of Anambra State, Nigeria.

The researchers used random sampling techniques to pick 200 rural entrepreneurs from the five communities: 40 from each community. As there was no known list of rural entrepreneurs in Oyi LGA, the researchers adopted the method of registering and including entrepreneurs they met in the commercial centres and markets in the four communities, who showed willingness to participate. A major criterion for inclusion was that the person had recently established an agro-allied rural enterprise or was involved in the use of any innovative agricultural farm technology.

The main instrument for data collection was 24-item structured questionnaires that were administered to 200 respondents. The questionnaires were divided into five sections dealing with socioeconomic profiles of respondents, the meaning of entrepreneurship and the role of entrepreneurship in rural development, challenges of rural entrepreneurship and suggested solutions to the challenges.

In Section $\mathrm{A}$ of the questionnaire, information solicited from the respondents included age, gender, educational background, experience in business, occupation and income. Sections B to E are Likert-type scales comprising fourresponse ratings of strongly agree (4), agree (3), disagree (2), and strongly disagree (1), which the respondents are requested to use to indicate their level of agreement with each of the items in 1 to 24 . A theoretical mean value of 2.5 was taken as a criterion to judge the means for the items in the respective sections. Therefore, any item in the instrument that had a mean equal to or greater than 2.5 was regarded as 
Box 1: Problems faced by small- and medium-scale enterprises and suggested initiatives to solve them.

\begin{tabular}{|c|}
\hline $\begin{array}{l}\text { Problems } \\
\text { Technical Assistance: } \\
\text { - High costs } \\
\text { - Few support institutions }\end{array}$ \\
\hline $\begin{array}{l}\text { Entrepreneurial Attitude: } \\
\text { - Tendency towards isolation } \\
\text { - Lack of organisation and integration } \\
\text { Little willingness to undertake associative entrepreneurial projects }\end{array}$ \\
\hline $\begin{array}{l}\text { Financing: } \\
\text { - Limited access to financing, both for start-ups and expanding enterprises } \\
\text { - Lack of endorsement and guarantees. }\end{array}$ \\
\hline $\begin{array}{l}\text { Policy and Enabling Environment: } \\
\text { - Excessive regulations and formalities } \\
\text { - Political and economic instability }\end{array}$ \\
\hline $\begin{array}{l}\text { Gender Imbalances: } \\
\text { - Difficulties for women to start-up businesses } \\
\text { - Difficulties for women entrepreneurs to get access to support and finance services }\end{array}$ \\
\hline $\begin{array}{l}\text { Qualification of Human Resources: } \\
\text { - Little specialisation and training } \\
\text { - Low level of productivity } \\
\text { - Low valuation and encouragement to work }\end{array}$ \\
\hline $\begin{array}{l}\text { Market: } \\
\text { - Low share in the domestic market and almost no share in external markets } \\
\text { - Lack of expertise in the area of domestic and external marketing } \\
\text { - Lack of insight into product differentiation and other competitiveness issues }\end{array}$ \\
\hline
\end{tabular}

Source: UNDP, cited in Sherief (2008)

SMEs, small- and medium-scale enterprises.

agree, while items with less than 2.5 were regarded as disagree. All 200 copies of the administered questionnaires were returned properly filled out, thus representing $100 \%$ return rate. The statistical tools used to analyse responses from the respondents were descriptive statistics such as frequency distributions tables, average, percentages, standard deviations, etc.

\section{Results}

The responses of the rural entrepreneurs as contained in questionnaires are presented and discussed in Sections A to E below. Section A examines the socio economic characteristics of the respondents, while sections $\mathrm{B}$ to $\mathrm{E}$ examine the perceptions of the respondents with regard to meaning of entrepreneurship, the role of rural entrepreneurship, challenges and problems and suggested solutions.

\section{Section A: Characteristics of respondents}

The socio economic characteristics of the respondents are presented and discussed in Table 1.

Information in Table 1 reveals that the majority of the respondents were in the age range of $40-45$ years (35\%), while $25 \%$ and $20 \%$, respectively, were in the age range of $50-59$ years and $30-39$ years. The table also shows that the majority of the respondents were male (60\%). On the educational qualification, $60 \%$ of the respondents attended secondary school followed by $30 \%$ indicating having attended primary school. Of the respondents, $10 \%$ attended a tertiary institution. This finding proves that rural entrepreneurs in the area are fairly educated and are expected to be fairly informed on the nature about entrepreneurship and its role in the development

\section{Suggested Initiatives}

Preparation and training of national trainers/counsellors

- Application of successful experiences

Promotion and development of institutions for support services of technical kind

- Entrepreneurial training and preparations

- Dissemination of successful associative experiences

- Support to, and co operation with, existing business or entrepreneurial associations Training and preparation of enterprising young people
Touns

- Association - grouping

- Assistance in establishment of credit schemes targeting SMEs (mutual guarantee schemes, etc.)

- Identification of specific obstacles and bottlenecks

- Recommendations for change and improvement within these areas

Adaptation and adjustment of legal framework

- Entrepreneurial training and preparation

- Sharing of experiences and best practices for women entrepreneurs

- Assistance in establishment of micro credit schemes geared towards women

- Skills training

- Managerial training

- Improvement of the work environment, organisational climate

Entrepreneurial training and preparation

- Counselling and advisory services by qualified personnel

- Information links, regional and international networks

- Establishment of business / entrepreneur associations

Vertical integration (possible labour specialisation)
TABLE 1: Socioeconomic profiles of the respondents.

\begin{tabular}{llcc}
\hline Item & Range & Frequency & Percentage \\
\hline Age (years) & $20-29$ & 30 & 15 \\
& $30-39$ & 40 & 20 \\
& $40-49$ & 70 & 35 \\
& $50-59$ & 50 & 25 \\
& 60 and above & 10 & 5 \\
Gender & Female & 80 & 40 \\
& Male & 120 & 60 \\
Educational & Primary & 60 & 30 \\
qualification & Secondary & 120 & 60 \\
& Tertiary & 20 & 10 \\
Marital status & Married & 150 & 75 \\
Experience in & Single & 50 & 25 \\
business (years) & $<1$ & 20 & 10 \\
& $1-5$ & 170 & 85 \\
Entrepreneurial & 6 and above & 10 & 5 \\
activity/occupation & Rice milling & 20 & 10 \\
& Poultry farming & 50 & 25 \\
& Carpentry & 20 & 10 \\
& Cassava milling & 30 & 15 \\
Monthly income & Rice farming & 80 & 40 \\
(Naira) & $<10$ 000 & 80 & 40 \\
& 10 000-30 000 & 110 & 55 \\
\hline above 30 000 & 10 & 5 \\
\hline
\end{tabular}

Source: Field survey 2014

process. On marital status, it was noticed that the majority of the respondents were married (75\%). Most of the respondents have been in the business from 1 to 5 years. The major entrepreneurial or occupational engagements of the respondents were agriculture - rice farming, poultry farming, and cassava milling. Also, the table shows that $55 \%$ of the respondents on average received a monthly income of between N10 000 and N30 000. The significance of the magnitude of this reported income is appreciated when 
compared to the minimum monthly income in the state which is about N18 500 .

\section{Section B: Awareness of the meaning of entrepreneurship}

Table 2, which reveals the mean scores and standard deviations for all items on the meaning of entrepreneurship, shows that entrepreneurs in the Oyi LGA are quite conversant with the meaning of entrepreneurship. They agreed that it is a process of creating something new, nurturing it to grow for the rewards of financial and personal satisfaction. They also agreed that it is a process for identifying an opportunity within an existing enterprise and creating a profitable reality for the enterprise from this opportunity. In particular the respondents agreed that rural entrepreneurship is the process of creating something new, seeing it grow for monetary and personal satisfaction and that entrepreneurship is a process of creating an entirely new venture by utilising local resources for the purpose of making profit.

\section{Section C: Role of rural entrepreneurship}

On the role of entrepreneurship in the rural development, the mean scores in Table 3 indicate that the respondents agreed that it reduces wastage of rural resources, creates employment, reduces rural-urban migration, creates wealth and increases income, and improves the standard of living of the rural dwellers. The respondents however disagreed that rural entrepreneurship increases output and prevents rural unrest.

\section{Section D: Challenges of rural entrepreneurship}

Information in Table 4 that sought to obtain the perceptions of the respondents on the challenges of rural entrepreneurship revealed that (based on the mean scores) neglect by the government, inadequate infrastructures, poor knowledge about emerging markets and corruption posed the greatest challenges to rural entrepreneurship. Other challenges included the lack of facilities for manpower development and inadequate finance.

\section{Section E: Solution to challenges}

We also sought to know the opinion of the respondents on how they think the challenges of entrepreneurs could be overcome. Based on the mean scores of the responses in Table 5, the respondents agreed that solutions could be found when local resources and assets are identified and converted to entrepreneurial activity. They also agreed that generating local community support for entrepreneurship would increase chances of a successful venture and that the local communities should be made attractive by establishing and updating infrastructures. The respondents finally agreed that there is a need to foster grassroots innovation.

\section{Summary and discussion of findings}

The following major findings were made:

TABLE 2: Understanding the meaning of entrepreneurship and rural entrepreneurship $(n=200)$.

\begin{tabular}{|c|c|c|c|c|}
\hline$S / n$ & Item & Mean & Standard deviation & Decision \\
\hline 1. & Process of creating something new, nurturing it to grow for the rewards of financial and personal satisfaction & 3.1500 & 1.06719 & Agree \\
\hline 2. & $\begin{array}{l}\text { Process for identifying an opportunity within an existing enterprise and creating a profitable reality for the } \\
\text { enterprise from this opportunity }\end{array}$ & 3.2500 & 0.89188 & Agree \\
\hline 3. & Creating and building something of value from practically nothing & 3.2600 & 0.89465 & Agree \\
\hline 4. & $\begin{array}{l}\text { Rural entrepreneurship means the process of Creating something new, seeing it grow for monetary and } \\
\text { personal satisfaction }\end{array}$ & 3.3900 & 0.79003 & Agree \\
\hline 5. & Process of creating entirely new venture by utilising local resources for the purpose of making profit & 3.4700 & 1.13222 & Disagree \\
\hline
\end{tabular}

Source: Field survey 2014

TABLE 3: The role of rural entrepreneurship in rural development $(n=200)$.

\begin{tabular}{|c|c|c|c|c|}
\hline $\mathrm{S} / \mathrm{N}$ & Item & Mean & Standard deviation & Decision \\
\hline 7 & Creation of employment & 2.9600 & 1.10937 & Agree \\
\hline 8 & Increasing output & 2.5100 & 1.16758 & Agree \\
\hline 9 & Improving the standard of living of the rural dwellers & 2.7800 & 1.07853 & Agree \\
\hline 10 & Creation of wealth and increase in income & 2.8300 & 1.13756 & Agree \\
\hline 11 & Reduction of wastage of local resources & 3.1000 & 0.95874 & Agree \\
\hline 12 & Prevents rural unrest & 2.4900 & 1.16771 & Disagree \\
\hline 13 & Reduce rural-urban migration and youth restiveness & 2.8900 & 1.03372 & Agree \\
\hline
\end{tabular}

Source: Field survey 2014

\begin{tabular}{|c|c|c|c|c|}
\hline$S / N$ & Items & Mean & Standard deviation & Decision \\
\hline 14 & Inadequate finance & 2.5400 & 1.14080 & Agree \\
\hline 15 & Corruption & 3.1400 & 0.95367 & Agree \\
\hline 16 & Lack of facilities for manpower development & 2.9800 & 1.02474 & Agree \\
\hline 17 & Neglect by the government & 3.2600 & 0.91696 & Agree \\
\hline 18 & Poor knowledge about emerging markets & 3.2000 & 0.92113 & Agree \\
\hline 19 & Inadequate infrastructure & 3.2400 & 0.93333 & Agree \\
\hline
\end{tabular}

Source: Field survey 2014 
TABLE 5: Distribution on solution to challenges of rural entrepreneurs.

\begin{tabular}{lllc}
\hline S/N & Items & Mean & Standard deviation \\
\hline 20 & $\begin{array}{l}\text { Generating local community support for entrepreneurship to increase } \\
\text { chances of a successful venture }\end{array}$ & 3.1400 & 0.94302 \\
21 & $\begin{array}{l}\text { Making the communities attractive by establishing and updating } \\
\text { infrastructure }\end{array}$ & 3.1400 & Agree \\
22 & $\begin{array}{l}\text { Identifying local resources and assets and converting them into } \\
\text { entrepreneurial activity }\end{array}$ & 3.1700 & Agree \\
24 & Fostering grassroots innovation & 3.0400 & 0.96421 \\
\hline
\end{tabular}

Source: Field survey 2014

Majority of the respondents were in the age range of $40-45$ $(35 \%)$. Gender-wise, $60 \%$ of the respondents were male $(60 \%)$ while $70 \%$ had at least secondary school education. Of the respondents, $75 \%$ were married. Also most of the respondents are engaged in agricultural activities and have been in business for between 1 and 5 years. The respondents were equally found to be earning between N10 000 and N30 000, which was even higher than the state's minimum income.

The study has shown that rural entrepreneurs in the Oyi LGA are fairly informed on the meaning of entrepreneurship. Particularly interesting is the strong agreement by most of the respondents that entrepreneurship is the process of creating an entirely new venture by utilising local resources for the purpose of making profit.

The place and the role of rural entrepreneurship in rural development are well appreciated by the rural entrepreneurs in the Oyi LGA. They agreed with the fact that entrepreneurship can help reduce wastage of local resources, reduce rural urban drift, create employment, improve the standard of living and help in rural wealth creation. These findings are important because they represent processes that bring about rural development. Obviously, they appear to endorse the contention of Petrin (1994) when he wrote that stakeholders in rural development now see entrepreneurship as a strategic development intervention that could accelerate the rural development.

The challenges facing rural entrepreneurs included neglect by the government, poor infrastructures, corruption and poor knowledge about emerging markets, lack of facilities for manpower development and inadequate finance, among others. These findings agree with those of OECD (2010) and Desaisa (2009), who found that rural entrepreneurs in developing countries are often challenged by such factors as lack of knowledge about emerging markets, lack of access to capital, lack of training and education programmes, isolation, unfavourable government policies and neglect, lack of access to reliable infrastructures, lack of competitive culture and corruption. It does appear that much of the problems that hinder entrepreneurship have to do with general lack of facilities and neglect of the rural sector. Clearly, rural entrepreneurs cannot be expected to contribute maximally to the development process when sufficient efforts are not made to create a favourable enabling environment in the rural sector.

The responding entrepreneurs are in agreement that solution to the challenges of rural entrepreneurship could be achieved when local resources and assets are identified and converted to entrepreneurial activity. They also agreed that generating local community support for entrepreneurship would increase chances, of a successful venture and that the local communities should be made attractive by establishing and updating infrastructures. These suggestions have merit and have wide support in the literature. Popovich and Buss (1990) noted that maximising the contribution of micro enterprises to development of rural areas requires policies that achieve macroeconomic stability, high quality physical, legal and communications infrastructures, technical assistance in education and training, access to new or existing markets, financing alternatives and access to capital, and other measures to lower barriers to business creation (see also Lee \& Phan 2008; OECD 2010).

\section{Conclusion and recommendations}

It is obvious that rural entrepreneurs are very knowledgeable about the meaning of entrepreneurship and role of entrepreneurship in the development process. Rural entrepreneurship was seen from the findings to be very important because of their role in development of rural areas such as ability to reduce rural-urban migration, waste of local resources, etc. However, they require an enabling environment such as government support and provision of infrastructures. We acknowledge that there have been arguments that policies and programmes targeted specifically to the development of rural entrepreneurship are not necessary, as entrepreneurship does not differ much with regard to location (Petrin 1994). Indeed, Petrin (1994) asserted that the needs of a rural-based 'would-be entrepreneur' or an existing small business do not differ much from those in an urban area. But access to entrepreneurial inputs (such as capital, management, technology, buildings, communications and transportation infrastructure, distribution channels and skilled labour) is much easier in the urban sector than in the rural areas (Petrin 1994). We believe that given the peculiar nature of the rural sector and its relative investment unattractiveness, much progress can be made when efforts are intensified to nurture and promote rural entrepreneurship.

Based on the findings and conclusion above, the researchers recommend the following:

1. Rural areas should be made as attractive as urban areas in terms of infrastructure provisions. Provision of infrastructural facilities such as accessible roads, communication facilities, electricity and security will go a long way to create an enabling environment for entrepreneurial activities to thrive. 
2. Policies that will take entrepreneurs to their roots should be mapped out in order to encourage urban entrepreneurs to develop their businesses in the rural areas.

3. There is a need to connect rural entrepreneurs to external markets, including assisting them in sourcing their inputs or merchandise and selling their products in urban and distant markets. This will bring the spirit of competitiveness and thus boost their morale.

4. As most rural dwellers are engaged in agricultural and food production businesses, innovation should be encouraged through training and extension services, provision of agricultural credit at concessionary interest rates, and plant hire services, among others. When these are provided, they will bring about the much-needed panacea to the challenges that constrain the efforts of rural entrepreneurs.

5. Government support is highly needed for the success of rural entrepreneurs. Therefore, policies and financial assistance from the government and its agencies should be extended to the rural sector to create an enabling environment.

\section{Acknowledgements \\ Competing interests}

The authors declare that they have no financial or personal relationships that may have inappropriately influenced them in writing this article.

\section{Authors' contributions}

F.N. was the research leader and was also responsible for data analysis and interpretation. C.S.O. was responsible for the literature search and review.

\section{References}

Agbola, M. \& Ukaegbu, C., 2006, 'Business environment and entrepreneurial activity in Nigeria: Implications for industrial development', Journal of Modern African Studies 44(1), 1-30. https://doi.org/10.1017/S0022278X05001394

Akhakpe, I., Fatile, O.J. \& Igbokwe-lbeto, C.J., 2012, 'Local government and the challenges of community and rural development in Nigeria: The way forward', International Journal of Asian Social Science 2(6), 803-819.

Brain, T., 2005, The role of the entrepreneurship, viewed 19 June 2010, from http:// www.entrepreneurship.com/startinga/business/startupbasics/article.78478. htm

Di-Masi, P., 2008, 'Defining entrepreneurship', viewed 13 June 2017, from http:// www.gdrc.org/icm/micro/define-micro.html
Di-Masi, P., 2000, 'Defining entrepreneurship', in Financing microenterprises: Theory and practice, viewed 19 June 2016, from http://www.gdrc.org/icm/micro/definemicro.html

Deji, O., 2005, 'Membership of co-operative societies and adoption behaviour of women farmers: Implication for rural development'. Journal of Social Science 10(2), 145-147.

Desaisa, M., 2009, Entrepreneurship in Iraq: Understanding the constraints, viewed 20 June 2010, from http://www.wider.unu.edu/publications/newsletter/articles/ en-GBlen

Ebiriwa, O.M., 2005, Understanding development administration, Outright Publishers Ltd., Onitsha.

Egwemi V. \& Odo, L.U., 2013, 'Rural development and poverty eradication in Nigeria', JORIND 11(1), 101-110.

Ejiofor, P., 1989, Foundations of business administration, Africana FEP Publishers Ltd., Onitsha.

Gana, J.S., 2001, Entrepreneurship, Kaduna Tofegan Associates, Kaduna.

Hisrich, R.D. \& Peters, M.P., 2002, Entrepreneurship, 5th edn., McGraw-Hill/Irwin, Sydney.

Lee, H.S., \& Phan, P., 2008, Initial thoughts on a model of rural entrepreneurship in developing countries, 2 nd edn., World Entrepreneurship Forum, Baltimore.

Naudes, W., 2008, Entrepreneurship in economic development, viewed 13 June 2017, from http://www.wider.Unu.edu/publications/working ers/research papers/2008GB/rp2008-2010

Nwobi, T., 2007, Rural development, theories and strategies, Rex Charles and Patrick Ltd., Nimo, Anambra State.

Nzelibe, C., 1996, Entrepreneurship and management of small scale business, Optimal Publishers, Enugu.

OECD, 2010, Rural entrepreneurship, viewed 25 May 2010, from http://www.oecd. org/document/55/0,3343,en-217136/-38013663-38040311-11,0

Okeke, M.I. \& Eme, O.I., 2014, 'Challenges facing entrepreneurship in Nigeria', Sinaporean Journal of Business Economics, and Management Studies 3(5), 18-34. https://doi.org/10.12816/0010956

Onibokun, A.G., 1987, 'Rural development policy planning and implementation in Nigeria', Journal of the Nigeria 7(2), 20-34.

Onyekwelu, R., Uzor, N. \& Chiekezie, N., 2008, Principles and practice of entrepreneurship, Rex Charles and Patrick Ltd., Imo, Anambra State.

Perpar, A., 2007, Characteristics of rural area in Slovenia, advantages, weakness, possibilities for improvement of present situation from view point of sustainable rural development, viewed 2 June 2014, from http://www.agri.hr/jcea/issues/ jcea8-2/Rdf/jcea82-14.pdf

Petrin, T., 1992, 'Partnership and institution building as factors in rural development', paper presented at the Sixth Session of the FAO/ECA Working Party on Women and the Agricultural Family in Rural Development, Innsbruck, Austria, 13-16 October.

Petrin, T., 1994, 'Entrepreneurship as a an Economic Force in Rural Development', key note paper presented at the 7th FAO/REU International Rural Development Summer School, Herrsching, Germany, 8-14 September, viewed 13 July 2017 from http://www.fao.org/docrep/w6882e/w6882eO2.htm

Popovich, M.G. \& Buss, T.F., 1990, '101 ideas for stimulating rural entrepreneurship and new business development', Economic Development Review 8(4), 26-32.

Redmond, W.A., 2008, Entrepreneur Microsoft (R) Encarta (R) 2009 \{DVD\} Microsoft Corporation.

Sherief, S., 2008, Entrepreneurship as an economic force in rural development, viewed 28 October 2015, from http://www.africaeconomicanalysis.org/articles/gen/ rural_entrepreneurship.ht

Umebali, E. \& Akuibilo, C.J.C., 2006, 'Readings in cooperative economics and management', in E.E. Umebali (ed.), Rural resources farm business management and rural development, Computer Edge Publishers, Lagos.

World Bank, 2015, World development indicators: Rural environment and land use. World Bank Group, Washington, DC. Available from http://wdi.worldbank.org/ table/3.1 